\title{
Study of the Effects of Decreasing Molecular Rigidity on Mesomorphism
}

\author{
Vinay.S.Sharma, B.B.Jain and R.B. Patel \\ Chemistry Department, K.K. Shah Jarodwala Maninagar Science College, Gujarat University, \\ Ahmedabad, Gujarat, India
}

E mail address: vinaysharma3836@gmail.com, roshanpatel770@gmail.com

Keywords: Chalconyl LC, Smectic, Nematic, Odd-even, Monotropy.

\begin{abstract}
A Chalconyl homologous series: $\mathrm{RO}-\mathrm{C}_{6} \mathrm{H}_{4}-\mathrm{CH}=\mathrm{CH}-\mathrm{CO}-\mathrm{C}_{6} \mathrm{H}_{4}-\mathrm{OC}_{14} \mathrm{H}_{29}(\mathrm{n}$ ) (meta) is synthesized and studied with a view to understand and establish the effect of molecular structure on Liquid crystal behaviour by reducing molecular rigidity through diminishing of a phenyl ring and a central carboxy or vinyl carboxy group from a molecule. Novel series consists of thirteen homologues $\left(\mathrm{C}_{1}\right.$ to $\left.\mathrm{C}_{18}\right)$. First member $\left(\mathrm{C}_{1}\right)$ homologue is nonliquid crystal and the rest of the homologues $\left(\mathrm{C}_{2}\right.$ to $\left.\mathrm{C}_{18}\right)$ are enantiotropically $\left(\mathrm{C}_{2}\right.$ to $\left.\mathrm{C}_{5}\right)$ nematogenic or monotropically $\left(\mathrm{C}_{6}\right.$ to $\left.\mathrm{C}_{18}\right)$ nematogenic plus smectogenic of low mesophaselengths and low transition temperatures $\left(38^{\circ} \mathrm{C}\right.$ to $76^{\circ} \mathrm{C}$ ). Transition temperatures were determined by an optical polarizing microscopy (POM) equipped with a heating stage. Cr-N/I, N-I, I-N, N-Sm transition curves behaved in normal manner in a phase diagram. N-I and I-Sm transition curves exhibited odd-even effect. Textures of nematic phase are threaded or schlieren and that of the smectic phase are of the type A or C. Analytical, spectral and thermal data supported molecular structure of homologues. Thermal stability ( N-I/ I$\mathrm{N})$ of series for nematic is $67.5^{\circ} \mathrm{C}$ and that of the smectic is very low. Group efficiency order derived on the basis of thermal stability is as under. $-\mathrm{Cl}$ with $-\mathrm{C}_{6} \mathrm{H}_{4}$. COO- $>-\mathrm{OC}_{14} \mathrm{H}_{29}$ (n) without $-\mathrm{C}_{6} \mathrm{H}_{4}$. COO- with reference to central bridge $-\mathrm{CH}=\mathrm{CH}-\mathrm{CO}-$.
\end{abstract}

\section{INTRODUCTION}

Thermotropic liquid crystalline (LC) materials [1] of chalconyl derivative of two phenyl rings bonded through only $-\mathrm{CH}=\mathrm{CH}-\mathrm{CO}$ - central bridge are rarely reported. Present investigation is planned with a view to understand and establish the effect of molecular structure on mesomorphic behaviour with reference to absence of one phenyl ring bonded through carboxy or vinyl carboxy central bridge, affecting molecular rigidity; in combine with molecular flexibility [2,3,4,5]. Reduction in molecular rigidity may lower transition temperatures which may be useful for LC devices [6,7] and the presence of chalconyl central bridge may act properly as antibacterial, antifungal, antimalarial and anticancer etc. etc. for pharmaceutical preparations $[8,9,10,11,12,13]$. Number of homologues series of chalconyl esters have been reported till the date $[14,15,16,17,18]$. Chalconyl derivatives of two phenyl rings will be synthesized, characterised and their thermometric properties will be studied, interpreted and discussed in terms of molecular rigidity and flexibility. Group efficiency order will be derived.

\section{EXPERIMENTAL}

\section{Synthesis}

Alkylation of 4-hydroxy benzaldehyde to give 4-n-alkoxy benzaldehyde is carried out by reported method [19] and alkylation of 3-hydroxy acetophenone to convert 3-n-tetradecyloxy acetophenone is carried out by reported method [20]. Thus, chalconyl homologue derivatives (C) was prepared by usual establish method [21], Products were collected and filtered, washed with ethanol solution dried and purified till constant transition temperatures obtained using an optical polarising microscope, equipped with a heating stage. Alkyl halides, EtOH, KOH, 3-Hydroxy acetophenone, 4-Hydroxy benzaldehyde etc., required for synthesis were used as received except solvents which were dried and distilled prior to use. The synthetic route to the series is mentioned below as scheme-1 


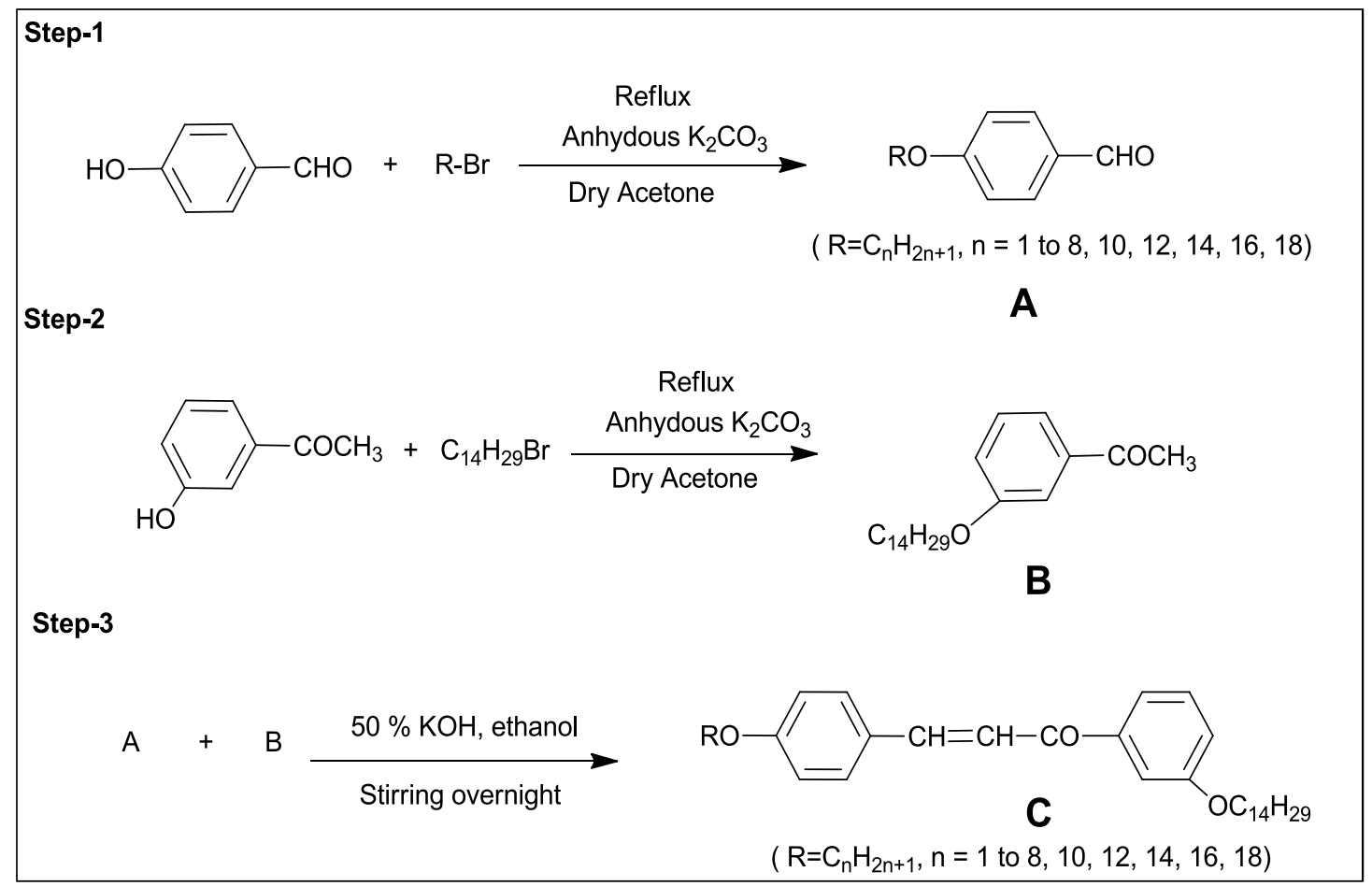

Scheme 1: Synthetic route to the series

\section{CHARACTERIZATION}

Representative homologues of a series were characterised by elemental analysis, Infrared spectroscopy, ${ }^{1} \mathrm{H}$ NMR spectra, IR spectra were recorded on Perkin-Elmer spectrum GX, ${ }^{1} \mathrm{H}$ NMR spectra were recorded on Bruker using $\mathrm{CDCl}_{3}$ as solvent. Microanalysis was performed on PerkinElmer PE $2400 \mathrm{CHN}$ analyser (table-1). Transition temperature ( table-3) and LC properties (Textures) were determined using an optical polarising microscopy equipped with heating stage and digital camera (POM). Texture of nematic phase were determined by miscibility method (table-2), thermodynamic quantities enthalpy $(\Delta H)$ and entropy $(\Delta S=\Delta H / T)$ are qualitatively discussed.

\section{Analytical Data:}

Table 1: Elemental Analysis for (1) Octyloxy (2) Dodecyloxy (3) Tetradecyloxy and (4) Octadecyloxy derivatives

\begin{tabular}{|c|c|c|c|c|c|}
\hline Sr. No. & $\begin{array}{c}\text { Molecular } \\
\text { formula }\end{array}$ & \multicolumn{2}{|c|}{$\begin{array}{c}\text { Elements \% } \\
\text { found }\end{array}$} & \multicolumn{2}{c|}{$\begin{array}{c}\text { Elements \% } \\
\text { Calculated }\end{array}$} \\
\cline { 3 - 6 } & & $\mathrm{C}$ & $\mathrm{H}$ & $\mathrm{C}$ & $\mathrm{H}$ \\
\hline 1 & $\mathrm{C}_{37} \mathrm{H}_{56} \mathrm{O}_{3}$ & 79.96 & 10.16 & 81.02 & 10.21 \\
\hline 2 & $\mathrm{C}_{41} \mathrm{H}_{64} \mathrm{O}_{3}$ & 81.40 & 10.42 & 81.45 & 10.59 \\
\hline 3 & $\mathrm{C}_{43} \mathrm{H}_{68} \mathrm{O}_{3}$ & 81.58 & 10.60 & 81.64 & 10.75 \\
\hline 4 & $\mathrm{C}_{47} \mathrm{H}_{76} \mathrm{O}_{3}$ & 81.86 & 10.94 & 81.97 & 11.04 \\
\hline
\end{tabular}

Table 2: Texture of Nematic Phase of $\mathrm{C}_{6}, \mathrm{C}_{8}, \mathrm{C}_{10}, \mathrm{C}_{12}$ by miscibility method.

\begin{tabular}{|c|c|c|}
\hline Sr. No. & Homologue & Texture \\
\hline 1 & $\mathrm{C}_{6}$ & Threaded \\
\hline 2 & $\mathrm{C}_{8}$ & Threaded \\
\hline 3 & $\mathrm{C}_{10}$ & Schlieren \\
\hline 4 & $\mathrm{C}_{12}$ & Schlieren \\
\hline
\end{tabular}




\section{IR Spectra in $\mathbf{c m}^{-1}$ for Dodecyloxy \& Octadecyloxy Derivatives:}

Dodecyloxy: 2914 ( C-H str. of alkane), 2848 (C-H str. of $-\left(\mathrm{CH}_{2^{-}}\right)$n group of $-\mathrm{OC}_{12} \mathrm{H}_{25}$ alkyl chain, $1660(\mathrm{C}=\mathrm{O}$ str. of carbonyl carbon of chalconyl group), 1604 ( $\mathrm{C}=\mathrm{C}$ str. of alkene), 1510, 1560 ( $\mathrm{C}=\mathrm{C}$ str. of aromatic ring), 999 ( $\mathrm{C}-\mathrm{H}$ bending of alkene), 1178 ( $\mathrm{C}-\mathrm{O}$ str. of ether linkage), 1288, 1246 ( C-O str. of carbonyl group), 770 Polymethylene $\left(-\mathrm{CH}_{2-}\right)$ of $-\mathrm{OC}_{14} \mathrm{H}_{29}, 675$ Polymethylene ($\mathrm{CH}_{2}$-)n of $-\mathrm{OC}_{12} \mathrm{H}_{25}$, 823( $-\mathrm{C}-\mathrm{H}$ - def. $\mathrm{m}$ di-substituted-Para), IR data confirms the molecular structure.

Octadecyloxy: 2916 ( C-H str. of alkane), 2850 (C-H str. of $-\left(\mathrm{CH}_{2}-\right)$ n group of $-\mathrm{OC}_{18} \mathrm{H}_{37}$ group, $1660(\mathrm{C}=\mathrm{O}$ str. of carbonyl group of chalconyl group), $1604(\mathrm{C}=\mathrm{C}$ str. of alkene), $1579(\mathrm{C}=\mathrm{C}$ str. of aromatic ring), 1004, ( C-H bending of alkene), 1199 ( C-O str. of ether linkage), 1251 ( C-O str. of carbonyl group), 770 Polymethylene $\left(-\mathrm{CH}_{2}-\right)$ of $-\mathrm{OC}_{14} \mathrm{H}_{29}, 823$ (-C-H- def. m di-substituted-Para), IR data confirms the molecular structure.

${ }^{1} \mathrm{HNMR}$ spectra in $\mathrm{CDCl}_{3}$ in $\boldsymbol{\delta}$ ppm for Heptyloxy \& Decyloxy Derivative:

Heptyloxy: $0.88\left(\mathrm{t}, 6 \mathrm{H},-\mathrm{CH}_{3}\right.$ of polymethylene $-\mathrm{C}_{6} \mathrm{H}_{13}$ and $\left.-\mathrm{C}_{14} \mathrm{H}_{29}\right), 1.79\left(\mathrm{p}, 10 \mathrm{H}, \mathrm{CH}_{3}-\mathrm{CH}_{2}-\right.$ $\mathrm{CH}_{2}-\mathrm{CH}_{2}-\mathrm{CH}_{2}$ - of $-\mathrm{OC}_{6} \mathrm{H}_{13}$ and $\left.-\mathrm{OC}_{14} \mathrm{H}_{29}\right), 1.28\left(\mathrm{~m}, 15 \mathrm{H}-\mathrm{CH}_{2}-\mathrm{CH}_{2}-\mathrm{CH}_{2}\right.$ - of $-\mathrm{OC}_{7} \mathrm{H}_{15}$ and $\left.\mathrm{OC}_{14} \mathrm{H}_{29}\right), 1.31$ (q, 8H, $\left.-\mathrm{CH}_{2}-\mathrm{CH}_{3}\right), 4.06\left(\mathrm{t}, 4 \mathrm{H},-\mathrm{OCH}_{2}-\mathrm{CH}_{2}-\right), 7.59$ (d, 2H, $\left.-\mathrm{CH}=\mathrm{CH}-\right), 7.43,7.28$ \& $7.83(4 \mathrm{H}$, meta substituted phenyl ring), $7.56 \& 7.97(4 \mathrm{H}$, phenyl ring with alkoxy chain). NMR data confirms the molecular structure.

Decyloxy: $0.88\left(\mathrm{t}, 6 \mathrm{H},-\mathrm{CH}_{3}\right.$ of $-\mathrm{C}_{10} \mathrm{H}_{21}$ and $\left.-\mathrm{C}_{14} \mathrm{H}_{29}\right), 1.80\left(\mathrm{p}, 10 \mathrm{H}, \mathrm{CH}_{3}-\mathrm{CH}_{2}-\mathrm{CH}_{2}-\mathrm{CH}_{2}-\mathrm{CH}_{2}-\mathrm{CH}_{2}\right.$ of $-\mathrm{OC}_{10} \mathrm{H}_{21}$ and $\left.-\mathrm{OC}_{14} \mathrm{H}_{29}\right), 1.28\left(\mathrm{~m}\right.$, polymethylene $16 \mathrm{H}-\mathrm{CH}_{2}-\mathrm{CH}_{2}-\mathrm{CH}_{2}$ - of $-\mathrm{OC}_{10} \mathrm{H}_{21}$ and $\left.\mathrm{OC}_{14} \mathrm{H}_{29}\right), 1.34\left(\mathrm{q}, 8 \mathrm{H},-\mathrm{CH}_{2}-\mathrm{CH}_{3}\right), 4.05\left(\mathrm{t}, 4 \mathrm{H},-\mathrm{OCH}_{2}-\mathrm{CH}_{2}-\right), 7.59(\mathrm{~d}, 2 \mathrm{H},-\mathrm{CH}=\mathrm{CH}-)$ ) $7.43,7.28$ $\& 7.83(4 \mathrm{H}$, meta substituted phenyl ring), $7.56 \& 7.97$ (4H, phenyl ring), $6.95 \& 7.62$ (4H, phenyl ring with alkoxy chain). NMR data confirms the molecular structure.

Table 3: Transition temperature in ${ }^{\circ} \mathrm{C}$

\begin{tabular}{|c|c|c|c|c|}
\hline \multirow{2}{*}{ Sr.no } & \multirow{2}{*}{$\mathrm{R}=\mathrm{n}$-alkyl group } & \multicolumn{3}{|c|}{ Transition temperatures in ${ }^{0} \mathrm{C}$} \\
\cline { 3 - 5 } & & Smectic & Nematic & Isotropic \\
\hline 1 & $\mathrm{C}_{1}$ & - & - & 76.0 \\
\hline 2 & $\mathrm{C}_{2}$ & - & 56.0 & 72.0 \\
\hline 3 & $\mathrm{C}_{3}$ & - & 58.0 & 68.0 \\
\hline 4 & $\mathrm{C}_{4}$ & - & 51.0 & 67.0 \\
\hline 5 & $\mathrm{C}_{5}$ & - & $(48.0)$ & 63.0 \\
\hline 6 & $\mathrm{C}_{6}$ & $(40.0)$ & $(46.0)$ & 58.0 \\
\hline 7 & $\mathrm{C}_{7}$ & $(38.0)$ & $(50.0)$ & 55.0 \\
\hline 8 & $\mathrm{C}_{8}$ & $(41.0)$ & $(48.0)$ & 59.0 \\
\hline 9 & $\mathrm{C}_{10}$ & $(42.0)$ & $(46.0)$ & 60.0 \\
\hline 10 & $\mathrm{C}_{12}$ & $(39.0)$ & $(50.0)$ & 58.0 \\
\hline 11 & $\mathrm{C}_{14}$ & $(38.0)$ & $(52.0)$ & 64.0 \\
\hline 12 & $\mathrm{C}_{16}$ & $(43.0)$ & & 61.0 \\
\hline 13 & $\mathrm{C}_{18}$ & $(40.0)$ & & \\
\hline
\end{tabular}

( ) indicates monotropy 


\section{RESULTS AND DISCUSSION}

n-Alkoxy benzaldehyde on condensation with 3-tetra decyloxy acetophenone yielded $\alpha-4-n$ alkoxy phenyl- $\beta-3$ '-n-tetradecyloxy benzoyl ethylenes. Entire novel homologous series except first member of a series are liquid crystalline $\left(C_{2}\right.$ to $\left.C_{18}\right)$ in nature. $C_{2}$ to $C_{5}$ homologues are enantiotropic nematic, $\mathrm{C}_{6}$ to $\mathrm{C}_{18}$ homologues are monotropically nematogenic plus smectogenic, and $\mathrm{C}_{1}$ homologue is nonliquid crystalline. Transition temperatures (Table-2) of homologues were plotted versus the number of carbon atoms present in n-alkyl chain ' $R$ ' of left -OR group and then on linking, like or related transition points; the Cr-N/I, N-I or I-N and N-Sm transition curves are obtained as shown in a figure-1. N-I/I-N transition curve descended from $\mathrm{C}_{2}$ to $\mathrm{C}_{6}$ homologue and then almost linearly prolonged upto $\mathrm{C}_{18}$ homologue with overall descending tendency. N-Sm transition curve initially ascended at $\mathrm{C}_{10}$ and $\mathrm{C}_{16}$ and then slightly descended in normal manner. $\mathrm{Cr}$ $\mathrm{N}$ or Cr-I transition curve adopted zigzag path of rising and falling nature. Thus, all the transition curves of a phase diagram behaved in normal manner. Normally enantiotropic mesomorphism appears after monotropic mesomorphism, but in case of present novel series; enantiotropy appears first $\left(\mathrm{C}_{1}\right.$ to $\left.\mathrm{C}_{5}\right)$ and then monotropic mesomorphism appears for higher homologues $\left(\mathrm{C}_{7}\right.$ to $\left.\mathrm{C}_{18}\right)$ i.e. Sequential order of monotropy and enantiotropy in a series are reversed as compared to normal sequential order of mesophase appearance in monotropy and enantiotropy.

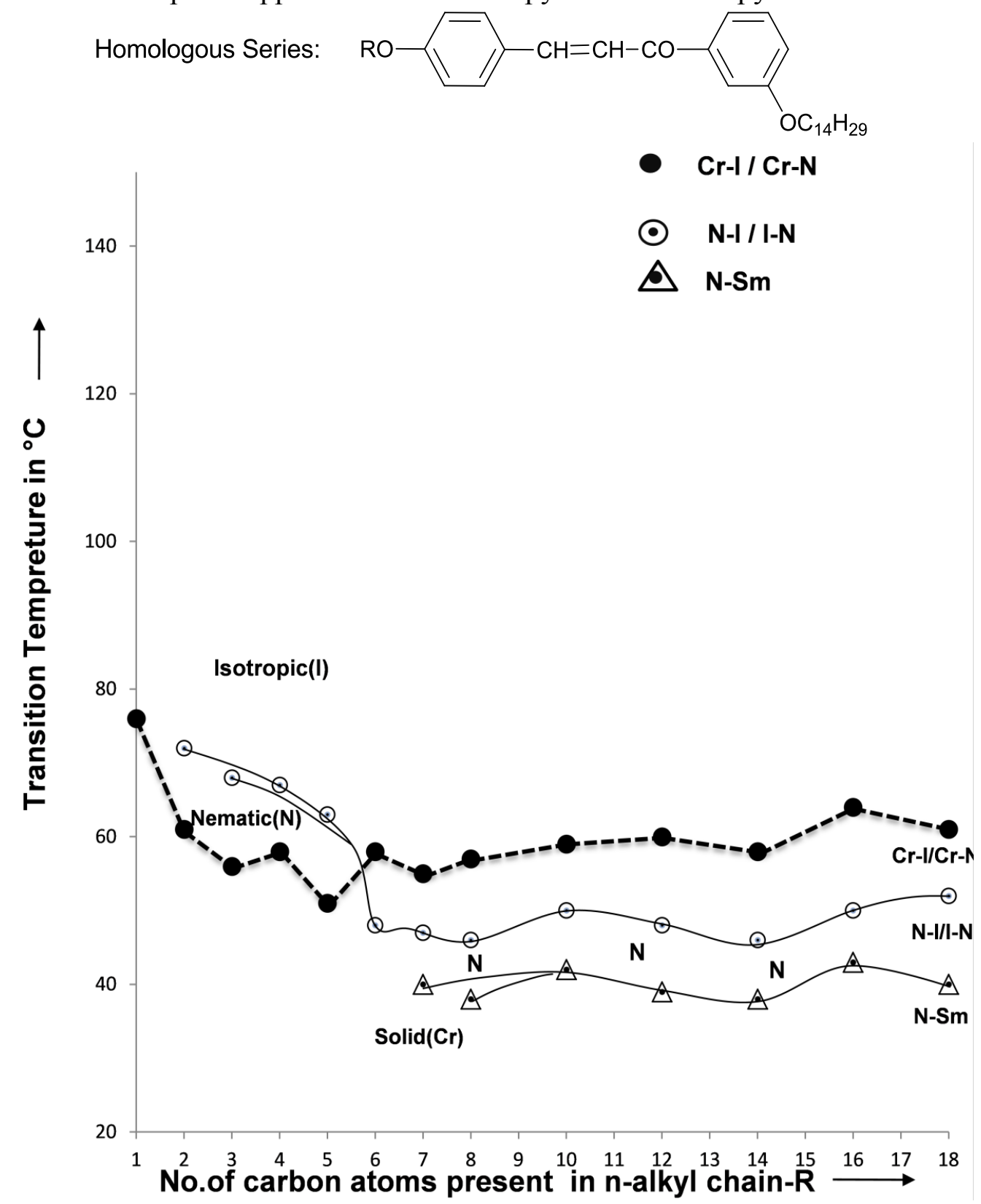

Figure 1: Phase diagram of series 1 
Thermometric properties of novel chalconyl derivatives are varied from homologue to homologue in the same series. Thermal stability for smectic and nematic are few ${ }^{\circ} \mathrm{C}$ and $67.5^{\circ} \mathrm{C}$ respectively. Mesophaselengths for smectic plus and nematic are $5.0^{\circ} \mathrm{C}$ and $12.0^{\circ} \mathrm{C}$. Thus, present novel series is low melting type and of low degree of mesomorphism. The exhibition of mesomorphism by $\mathrm{C}_{2}$ to $\mathrm{C}_{18}$ homologues either as enantiotropic or monotropic manner is attributed to suitable magnitudes of anisotropic forces of intermolecular end to end and lateral attractions as a result of favourable magnitudes of molecular rigidity and flexibility; induced by dispersion forces and dipole-dipole as well as electronic interactions. The intermolecular cohesive forces on heating a sample arrange the molecules of $\mathrm{C}_{2}$ to $\mathrm{C}_{5}$ homologues in stastically parallel orientational order. Therefore the molecules of $\mathrm{C}_{2}$ to $\mathrm{C}_{5}$ homologues exhibited enantiotropically nematogenic character. However, the molecules of higher homologues $\mathrm{C}_{6}$ to $\mathrm{C}_{18}$ of longer n-alkyl chain ' $\mathrm{R}$ ' of $-\mathrm{OR}$ end group initially transformed into isotropic state due to awkward accommodations of longer - OR and laterally substituted $-\mathrm{OC}_{14} \mathrm{H}_{29}$ (n) end groups. But, on cooling the same below isotropic temperature, the same molecules of isotropic mass, are growing and accommodate themselves in stastically parallel orientational order and then in an arrangement of sliding layered molecular reorganization in irreversible manner; to cause monotropic nematic and then smectic phase one after another. The lowering of transition temperature from lower to higher homologue is attributed to weakening of gradual intermolecular forces, with increasing addition of methylene unit or units. The diminishing of odd-even effect from and beyond $\mathrm{C}_{5}$ for nematic and $\mathrm{C}_{8}$ for smectic is attributed to the coiling or bending or flexing or coupling of longer n-alkyl chains with principal axis of the core structure of molecules from ' $\mathrm{R}$ ' and lateral meta $-\mathrm{C}_{14} \mathrm{H}_{29}$ tails; which induces uncertainty in molecular polarity and polarizability, affecting factors governing intermolecular cohesion and closeness. The reversal of sequential order for enantiotropic and monotropic mesomorphism may be due to presence of only and only $-\mathrm{CH}=\mathrm{CH}-\mathrm{CO}$ - central bridge. Observed odd-even effect and variations in LC properties are attributed to the sequentially added methylene unit or units. The absence of mesomorphism of $\mathrm{C}_{1}$ homologue is due to the low magnitudes of the dispersion forces and low dipole-dipole interactions units. The thermometric properties of present novel series-1 are compared with other structurally similar analogous series X[22] as mentioned below in figure- 2 .

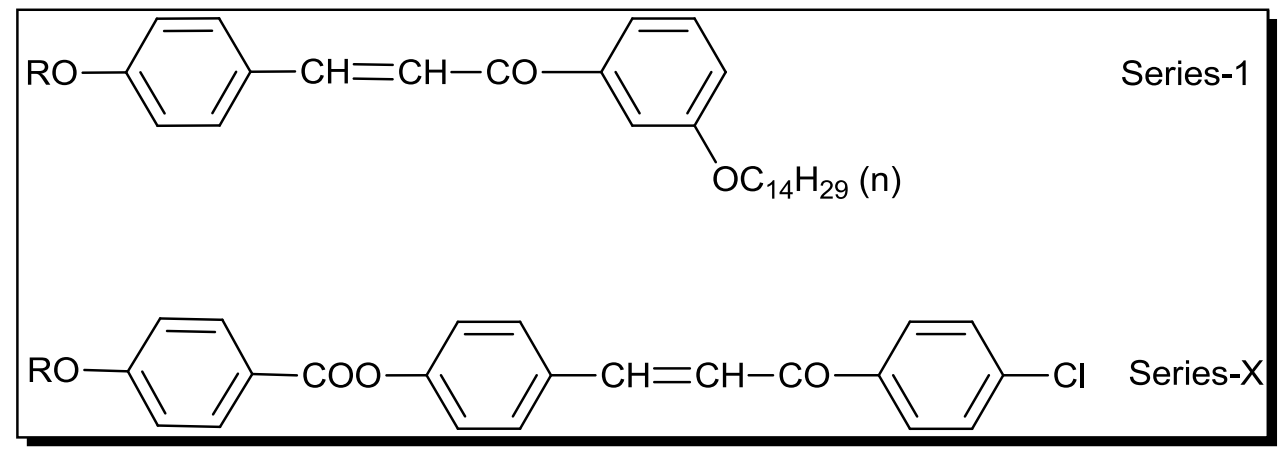

Figure 2: Structurally similar series

Homologous series(1) and $\mathrm{X}$ under comparative study are identical with respect to two phenyl rings bonded through chalconyl central bridge which fully contribute to total molecular rigidity of series- 1 and the partly contribute to series- $\mathrm{X}$ for the molecular part other than $-\mathrm{C}_{6} \mathrm{H}_{4}$ COO-. Secondly both series-1 and X are identical with respect to left flexible n-alkoxy (-OR) group for the same homologues from series to series; but differ from homologue to homologue in the same series contributing to total flexibility. Tailed ended meta substituted flexible $-\mathrm{OC}_{14} \mathrm{H}_{29}(\mathrm{n})$ group of series-1 and $-\mathrm{Cl}$ flexible group of series-X are of different group polarities contributing partly to total molecular flexibility which differed in magnitudes. Thus, total molecular rigidity and flexibility differed considerably for the series under comparison. Hence the variations in mesomorphic properties for the same homologue from series to series or from homologue to homologue in the same series will depend upon the differing magnitudes of molecular rigidity and flexibility between series-1 and X; under comparative study. Following table-3 represents some thermometric properties 
Table 3: Thermal stability in ${ }^{\circ} \mathrm{C}$

\begin{tabular}{|c|c|c|}
\hline Series $\longrightarrow$ & $\begin{array}{c}\text { (series-1) } \\
-\mathrm{C}_{14} \mathrm{H}_{29}(\mathrm{n})\end{array}$ & $\begin{array}{c}\text { ( series-X) } \\
-\mathrm{Cl}\end{array}$ \\
\hline $\begin{array}{l}\text { Sm-N or Sm-I or } \\
\text { I-Sm or N-Sm } \\
\text { Commencement of } \\
\text { Smectic phase }\end{array}$ & $\begin{array}{c}\text { Few degrees } \\
1 \text { to } 2^{\circ} \mathrm{C} \\
\left(\mathrm{C}_{6}-\mathrm{C}_{18}\right) \\
\mathrm{C}_{6}\end{array}$ & $\begin{array}{c}142.66 \\
\left(\mathrm{C}_{4}-\mathrm{C}_{16}\right) \\
\mathrm{C}_{4}\end{array}$ \\
\hline $\begin{array}{c}\text { N-I or I-N } \\
\text { Commencement of } \\
\text { Nematic phase }\end{array}$ & $\begin{array}{c}67.5 \\
\left(C_{2}-C_{5}\right) \\
C_{2}\end{array}$ & $\begin{array}{c}154.3 \\
\left(\mathrm{C}_{4}-\mathrm{C}_{14}\right) \\
\mathrm{C}_{3}\end{array}$ \\
\hline $\begin{array}{l}\text { Mesophaselength } \\
\text { upper and lower in } \\
{ }^{\circ} \mathrm{C}\end{array}$ & $\begin{array}{ll}05.0 & \text { to } 12.0 \\
\mathrm{C}_{8} & \mathrm{C}_{3} / \mathrm{C}_{5} / \mathrm{C}_{18}\end{array}$ & $\begin{array}{ccl}19.7 & \text { to } & 72.2 \\
\mathrm{C}_{4} & & \mathrm{C}_{14}\end{array}$ \\
\hline
\end{tabular}

From table-3, it is clear that,

- Presently investigated homologous series-1 and an analogous series-X under comparison are smectogenic and nematogenic.

- $\quad$ Smectogenic property commences from $\mathrm{C}_{6}$ homologue of series-1, but it commences earlier from $\mathrm{C}_{4}$ homologue of series-X.

- Nematogenic property commences from $\mathrm{C}_{2}$ homologue of present novel series-1 but it commences late from $\mathrm{C}_{3}$ homologue of series-X.

- Smectic and nematic thermal stabilities of series- 1 are much lower $\left(1\right.$ or $2^{\circ} \mathrm{C}$ and $\left.67.5^{\circ} \mathrm{C}\right)$ than a series-X ( 142.66 and 154.3).

- Mesophaselengths of series-1 are much lower than a series-X.

- Very short and sharp odd-even effect is exhibited by both series 1 and X under comparison.

- The normal sequence of monotropic mesomorphism and then enantiotropic mesomorphism appears for series-X, but exactly reversal of sequential order of mesophase appearance of mesomorphism appears i.e. enantiotropy first $\left(\mathrm{C}_{1}\right.$ to $\left.\mathrm{C}_{5}\right)$ and then monotropy for novel series1 is a striking feature.

The exhibition of smectic and nematic mesomorphism is attributed by suitable magnitudes of anisotropic forces of intermolecular attraction occurred for series- 1 and $\mathrm{X}$ as a consequence of favourable magnitudes of molecular rigidity and flexibility, which arranges molecules of mesogenic homologues in required organization of molecules as either sliding layered or stastically parallel orientational order monotropically or enantiotropically. The reverse order of monotropy and enantiotropy are attributed to the chalconyl central group present in absence of - COO- or $\mathrm{CH}=\mathrm{CH}-\mathrm{COO}$ - ester group in series-1, whereas, it is in normal order in case of series-X, which is attributed to the presence of chalconyl central group (-CH=CH-CO-) in presence of ester group. Thus presence or absence of ester group including addition or subtraction of a phenyl ring in a molecule can alter the normal order of monotropic and enantiotropic mesomorphism in a homologous series. Early or late commencement of mesophase or mesophases are related with the extent of molecular coplanarity. The molecules of series-1 consisted of two phenyl rings and one central bridge $-\mathrm{CH}=\mathrm{CH}-\mathrm{CO}$ - are more coplanar than the corresponding homologues of series-X, which results into early commencement of mesophase from $\mathrm{C}_{2}$ homologue of series- 1 and from later $C_{3}$ homologue of series- $X$ for nematic and reversal of it for smectic i.e. $C_{6}$ and $C_{4}$. The molecules of series- $\mathrm{X}$ consisted of three phenyl rings bonded through two central bridges are more rigid than the corresponding homologues of series-1 which have high resistivity towards exposed thermal vibrations ( higher $\Delta \mathrm{H}$ ) requires more energy to transact from one physical state to other physical state. Thus, the corresponding homologues of series- $\mathrm{X}$ are thermally more stable than a 
series-1 i.e. thermal stabilities and mesophaselengths of smectic and nematic phase of series-X are higher than a present series-1 under comparative study. Thus, the differing magnitudes of molecular rigidity and flexibility of molecular structure operate the difference in mesomorphic tendency of molecular structure.

\section{CONCLUSIONS}

- Novel chalconyl homologous series of two phenyl rings and one central bridge is predominately nematogenic and partly smectogenic whose degree of mesomorphism, mesophaselengths and thermal stabilities are low and of low ordered melting type.

- The group efficiency order derived for smectic and nematic on the basis of (a) thermal stability (b) early commencement of mesophase and (c) total mesophaselengths are as under.

(a) Smectic

$$
\text { para }-\mathrm{Cl} \text { with }-\mathrm{C}_{6} \mathrm{H}_{4} \text {. COO- }>\text { meta }-\mathrm{OC}_{14} \mathrm{H}_{29} \text { (n) without }-\mathrm{C}_{6} \mathrm{H}_{4} \text {.COO- }
$$

$\underline{\text { Nematic }}$

$$
\text { para }-\mathrm{Cl} \text { with }-\mathrm{C}_{6} \mathrm{H}_{4} \text {. COO- }>\text { meta }-\mathrm{OC}_{14} \mathrm{H}_{29} \text { (n) without }-\mathrm{C}_{6} \mathrm{H}_{4} \text {.COO- }
$$

(b) $\underline{\text { Smectic }}$

$$
\text { para }-\mathrm{Cl} \text { with }-\mathrm{C}_{6} \mathrm{H}_{4} \text {. COO- }>\text { meta }-\mathrm{OC}_{14} \mathrm{H}_{29} \text { (n) without }-\mathrm{C}_{6} \mathrm{H}_{4} \text {. COO- }
$$

$\underline{\text { Nematic }}$

$$
\text { meta }-\mathrm{OC}_{14} \mathrm{H}_{29} \text { (n) without }-\mathrm{C}_{6} \mathrm{H}_{4} \text {. COO- }>\text { para }-\mathrm{Cl} \text { with }-\mathrm{C}_{6} \mathrm{H}_{4} \text {. COO- }
$$

(c) $\underline{\text { (Smectic + Nematic) }}$

$$
\text { para }-\mathrm{Cl} \text { with }-\mathrm{C}_{6} \mathrm{H}_{4} \text {. COO- }>\text { meta }-\mathrm{OC}_{14} \mathrm{H}_{29} \text { (n) without }-\mathrm{C}_{6} \mathrm{H}_{4} \text {. COO- }
$$

- Mesomorphism is very sensitive and susceptible to a molecular structure as a consequence of favourable molecular rigidity and flexibility.

- $\quad$ Present study is useful for the study of binary systems, which may help to operate LC devices at room temperature or low temperature and homologues being bioactive, are useful for pharmaceutical preparations.

- The normal order of monotropy and enantiotropy is reversed by introducing only one and one chalconyl group between a molecule consisted of two phenyl rings as a central group instead of ester as central group between two phenyl rings.

- $\quad$ Present investigation supports and raises credibility to the conclusions drawn earlier, and adds some more generalisation.

\section{Acknowledgement}

Authors acknowledge thanks to Dr. R.R.Shah, principal and management of K. K. Shah Jarodwala Maninagar Science College, Ahmedabad. Authors are also thankful to Dr. A.V.Doshi, Ex-principal of M.V.M. Science and Home Sci. College-Rajkot for his constant support, inspirations and help and valuable comments and suggestions as and when we needed during the course of present investigation. Authors thank to NFDD Centre for the analytical and spectral services. 


\section{References}

[1] Reintitzer, F., Monatsh 9, 421 (1888).

[2] Hird, M., Toyne. K. J., and Gray G. W., Day S. E. and Mc. Donell D. G., (1993), Liq. Cryst. 15, PP. 123.

[3] Collings P. J. and Hird M.,(1997), Introduction of Liquid Crystals chemistry and physics, Taylor and Francis Ltd. U. K., 1998.

[4] Marcos, M., Omenat, A., Serrano, J. L. and Ezcurra, A., (1992), Adv. Matter, 4, 285.

[5] Hird, M., Toyne, K. J., Gray, G. W., Day, S. E., (1993) Liq. Cryst. 14, PP. 741.

[6] S. Naruma. Advance LCD technologies, Display 22 (1) (2001) PP.1

[7] Kim,W. S., Elston S. J. and Raynes F. P., Displays 29 (2008). PP. 458-463.

[8] Tadwee Imaran, Dr.Sahanashahi, VivekRamteke, Iftequar Syed, Liquid Crystals pharmaceutical Application: A review, IJPRAS, ISSN 2277-36. Vol. 1, Issue 2 (2012), 06-11.

[9] Gray G. W. and Winsor P. A. ( Eds ) Liquid Crystals and plastic crystals, chapter-6.2, The role of liquid crystal in life processesby Stewart G. T., Vol-1, PP. 308-326.

[10] C.A.Calliste, Bail le J.C, Trouilas P, Poug C, Chulia A.J, Duroux L.J., Anticancer, Res, (2001), 21, 3949-3956.

[11] Rajesh.G, Mansi.K, Srikant.K, Babasaheb.B, Nagesh.D, Kavita.S, Ajay.C., Chem. Pharm.Bull, (2008), 56, PP.897-901.

[12] Jain Upendra K., Bhatia Richa K., Akkipendly R. Rao, Ranjit Singh, SaxenaAjit K. And Seha Irun, "Design and DevelopmentofHelogenatedChalconederavatives as potential anticancer Agents" Tropical Journal of pharmaceutical Research, January 2014: 13 (1), 73-80.

[13] Gaikwad Prajakta P., Desai Maya T., "Liquid crystalline phase and its Pharma Application" International journal of Pharma Research and Review, Dec. (2013); 2 (12): 40-52.

[14] Doshi et al (i) Suthar D. M. and Doshi A. V., Mol. Cryst. Liq. Cryst. Vol. 575, PP 76-83. (ii) Chauhan H. N. and Doshi A. V., Mol. Cryst. Liq. Cryst. Vol. 570, PP. 92-100 (2013) (iii) Chaudhary R. P., Chauhan M. L. and Doshi A. V., Vol. 575, PP. 88-95 (2013) (iv) Bhoya U. C., Vyas N. N. and Doshi A. V, Mol, Cryst. Liq. Cryst. Vol. 552. PP. 104-110. (2012).

[15] D.Demus, 100 years of liquid crystal chemistry, Mol.Cryst.Liq., 165 (1988) PP. 45-84.

[16] Imrie, C. T. and Luckhrust,G. R., "Liquid Dimers and oligomers in handbook of Liquid crystal, low molecular liquid crystals; Vol. 28, Demus, D., Goodby, J. W., Gray G. W., Spiess, H. and V. Villeds, Willey-VCH weinhe 1998, PP-801-833.

[17] Demus, D., Plenary Lectures 100 years of liquid crystals chemistry, Thermotropic liquid crystals with conventional and unconventional molecular structures, Liq. Cryst. 5 (1998). PP. 75110.

[18] Suthar, D. M., Doshi A.A and Doshi A. V., "Study of liquid crystalline state and evaluation of its properties through a novel Homologous series", Mol. Cryst. Liq. Cryst. Vol. 582, PP. 79-87, 2013.

[19] Aurangzeb Hasan, Asghar Abbas, Muhammed Nadeem Akhtar., Molecule 16, 7789-7802 (2011).

[20] Nikitin K.V., Andryukhova N.P., Can.J.Chem., 82, 571, (2004).

[21] Furniss, B.S., Hannford, A. J., Smith, P. W.G.,andTatchell, A. R. (Revisors). (1989). Vogel's Textbook of Practical Organic Chemistry $\left(4^{\text {th }}\right.$ Edn.), longmann Singapore Publishers Pvt. Ltd.: Singapore, PP. 563-649.

[22] Rabhasia P.K. and Bhoya U.C., DOI: 101080/15421406, 1068994 paper accepted for publication in Mol.Cryst.Liq.Cryst.,(2015). 